\title{
Semantic Level Errors of Students' Scientific Work From Various Indonesian Island in the City of Madiun
}

\author{
Pramudita Septiani $^{1}$, Sarwiji Suwandi ${ }^{2}$, Budhi Setiawan ${ }^{3}$ \\ ${ }_{1,2,3}$ Postgraduate, Sebelas Maret University, Indonesia \\ pramuditya.09@gmail.com
}

\begin{abstract}
This study aims to explain and describe the language errors of semantic level in students' scientific work from various Indonesian islands in the city of Madiun. The study was conducted at two major universities in Madiun City. The type of research used in this research is a descriptive qualitative research through observation and field note techniques as data collection techniques. The result of the data is students' assignment papers. Data analysis techniques used in this study issharing methods or distribution methods with advanced techniques in the form of expansion (expansion) techniques and changing forms. The conclusions of this study are: (1) Usage error of similar words, consisting of (a) 88 errors of cognate pairing, (b) 79 errors of ambiguous pairing and (c) 65 errors of contended pairing. (2) Word choice (diction) errors, which consist of (a) 87 errors because do not meet the truth requirements, (b) 89 errors because do not meet the accuracy requirements, and (c) 90 errors because do not meet the standard requirements. In addition, errors in the word choices or diction occur due to factors influenced by the language that was mastered first.
\end{abstract}

Keywords : Semantic error; Scientific work; the city of Madiun

\section{Introduction}

Indonesia is a rich country, "gemah ripah loh jinawi" as the Javanese proverb describes it, which means peace and prosperity because of its rich natural resources and soil fertility. This saying is indeed very suitable if used as the Indonesian motto. Indonesia is a country with various miracles from God in it. Not only the natural resources and soil fertility that should be grateful for from Indonesia, various tribes, races, languages and religions also exist in Indonesia. As is known, Indonesia is a country with millions of islands, and each island can be inhabited by more than 8 tribes. For example, Java Island consists of Javanese, Sundanese, Madurese, Batavia, Osing tribe, Tengger tribe, Samin tribe, and Baduy tribe. Of course this underlies that the Indonesian people also have various languages, there are 668 languages from 2,468 areas of observation that have been identified by the department of Development and Language Guidance of Ministry of Education and Culture. The number of languages that already exist, only reaching 90\%, there are still areas of East Nusa Tenggara, Maluku, North Maluku, Papua, and West Papua that have not been fully identified (Machmudi, 2019).

As well as the City of Madiun, where this research, was conducted. The rapid economic development in the City of Madiun in the last 5 years made many people seek their fortune in the City of Madiun, not only in terms of the rupiah but also in terms of education. Madiun City is a municipality for 5 regencies namely; Madiun Regency, Ponorogo Regency, Pacitan Regency, Magetan Regency, and Ngawi Regency, it is not surprising that Madiun City is the centre of the economy. The rapid economic growth in the City of Madiun is marked by the presence of several malls, five-star hotels, education centres and other entertainment centres that now stand and will stand in the City of Madiun. Of course this has caused many migrants in the city of Madiun, not only from Java, but also from outside Java, such as; Sumatra Island, Kalimantan Island, NTT Island, NTB Island, Sulawesi Island, and even from Papua. 
This mixing of cultures and languages in the city ofMadiun often causes errors, especially in grammatical matters. It can be because of the influence of b1 brought by each newcomer or because of lack of understanding. The result of the observation found that there were still many grammatical system errors in the students' scientific work in the city of Madiun, especially students in the early semester of lectures. Scientific work is a form of academic culture in universities. Scientific work is a paper whosethe contents try to explain a scientific discussion conducted by a writer or researcher (Dalman 2015: 5).

The lecture domain in the higher education requires students to be able to make scientific work, besides being a form of student contribution to the improvement of science and technology, as well as a means of problem solving in society in the fields of science, social, health, etc., in this case, for the benefit of the whole community. In line with the opinions of Dwiloka and Riana, (2012: 1-2) who explained the purpose of scientific work, namely, developing science, technology, and art obtained through literature, collection of experiences, research, and knowledge of others beforehand.

Moreover, the ability to write scientific papers as a field for students adds financial strength, for example, RISTEK DIKTI (Ministry of Research, Technology and Higher Education) holds a grant program in the field of entrepreneurship with the aim of students become creative people who can develop their own products, by making proposals for submission in the form of scientific work. Even now there are many scholarships that require the students to make scientific works in their submissions, or have been made scientific papers that are indexed nationally or internationally.

Considering the importance of scientific work, RISTEK DIKTI also made various efforts, so that this culture flourishes in students' academic world. The RISTEK DIKTI's commitment was welcomed by all elements of higher institutions, this is marked from Indonesia's extraordinary achievement in the field of scientific publications at the ASEAN level which got the first rank in terms of scientific papers publication in international journals indexed in Scopus which reaches 33,183 articles, with 12,734 for journals and 19,399 for proceedings (Scopus, 25 July 2019). In addition, RISTEK DIKTI has also issued PERMENRISTEK DIKTI (Ministry of Research, Technology and Higher Education Regulations)Number 9/2018 on Scientific Journal Accreditation which is expected within the next two years there will be 7,000 national accredited journals with various ranks can be accessed by students (Zubaidah, 2018).

The important role of the Indonesian General Course (MKU-BI) which must be followed by all students in higher education also has a big role. MKU-BI in learning seeks to develop scientific writing skills for students with expectations that students can use Indonesian to express their thoughts, ideas, and scientific attitudes into various forms of quality scientific work (meeting the requirements: objectivity, coherence, cohesion, effectiveness, efficiency, and communicative). For this reason, it is very important to understand the rules of writing, including understanding linguistic rules (syntax, morphology, semantics, and spelling). In terms of development, MKU-BI not only teaches how to write scientific works, but also corrects errors in writing scientific works from the terms of systematic, structural and grammatical.

Semantic position in linguistics is a component that is contained in linguistics, as well as components of sound and grammar (Palmer, 1981: 5). Semantics is generally defined as the study of meaning (Lyons, 1971: 1). Mulyono (1964: 1) explained more detail that semantics is 
a branch of linguistics whose task is to study the word, how it starts, how it develops, and what causes changes in meaning in the language history.

Semantics in a slightintelligence is distinguished on two points, namely (1) reference theory (denotation of extension) and (2) theory of meaning (connotation, intention) (Suwandi, 2011: 4). Meanwhile, language errors that often occur at the semantic level, some experts try to explain include: Tarigan (1998: 46) stated that language errors that may occur in the semantic field are as follows: (1) The Application of Hypercorrect Symptoms; (2) Pleonasm symptoms; (3) Word choices or diction; (4) Ambiguity, ambiguity errors are divided into affix types, idiomatic types, reference and substitution types, and attribute types in sentences. Furthermore, Tarigan (1998), Alwi (2014: 21) divide the analysis of errors at the semantic level into: (1) Misuse of similar words, and (2) Error of word choices or diction. Mistakes in the use of similar words are classified into 3 groups, namely: (1) cognate pairing, (2) contended pairing, and (3) ambiguous pairing. While the best word choices are those that meet the requirementsas follow: (1) accuracy, (2) certainty, and (3) prevalence (Alwi et al, 1992: 11). This study more inclined to language errors in semantic level presented by Alwi( 2014).

Factors that cause language errors generally occur due to students' scientific work are as follow: (1) Influenced by the language that was mastered first, (2) Language users' lack of understanding over the use of the language, (3) Language teaching that is less precise or imperfect (Setyawati, 2017: 15). Errors at the semantic level reviewed from the student's background allow errors occur to be influenced by the first language or mother tongue mastered by the students before obtaining Indonesian. In addition, it will be known whether there is an error factor after being reviewed in the discussion.

Based on the explanation above, the problem statement in this research is how the language errors in semantic level on the students' scientific work from various Indonesian islands in the City of Madiun are. The purpose of this research is to explain and describe language errors in semantic level on the students' scientific work from various Indonesian islands in the City of Madiun.

Language errors analysis provides many advantages, especially those related to the process of preparing papers as a type of scientific work. In addition the choice of the research conducted in the City of Madiun because of the differences in the students' background who are expected to have more complex errors, which affects the occurrence of the language errors in semantic level on the students' scientific work from various Indonesian islands in the City of Madiun, more specifically on student assignment papers.

\section{Methodology}

This research uses descriptive qualitative research. Qualitative research is intended as a type of research whose findings are not obtained from statistical procedures or other forms of calculation (Strauss \& Corbin, 2009: 5). Meanwhile, descriptive methods are used because researchers want to explain or describe the result of data. This means that the result the data is explained using words, or sentences and not in the form of numbers or counts. In line with what explained by Nazir (2005: 73) that this descriptive method is intended to explain or describe the existing phenomena, both the natural phenomena and human scientific work.

The data source of this research was students' assignment paper, at two major universities in the City of Madiun namely, PGRI Madiun University and Widya Mandala Madiun Catholic University. Student papers were randomly drawn from various study programs and faculties, 
namely: Accounting, Accounting Education, Elementary School Teacher Education, Biology Education, Economic Education, Psychology, and Guidance and Counselling, for students who have received MKU-BI lectures.

The data collection technique in this research is observation methods continued with field note techniques. The observation method is done to observe the use of language. The term observing here is not only related to the use of spoken language, but also the use of written language (Mahsun, 2005: 92). Written data can be obtained from students' scientific work. The first thing done by the researchers is observing to all of the student papers' result, and then recording all types of errors. After knowing the types of errors in the syntactic field then analysed and corrected the errors.

\section{Results and Discussion}

Referring to the theory by Alwi (2014: 21-22) which divided the language errors at the semantic level into: (1) Misuse of words that are similar, and (2) Errors of word choices or diction. The misuse of similar words can be divided into: (1) errors of cognate pairing, (2) errors of contended pairing, and (3) errors of ambiguous pairing. The results of the misuse of similar words, in this study are as follows:

Table 1. Errors in Using Similar Words

\begin{tabular}{|c|c|}
\hline Type of Semantic Level Error & Amount \\
\hline 1. Mistakes in using similar words & \\
\hline a. errors of cognate pairing & $\mathbf{8 8}$ \\
\hline b. errors of ambiguous pairing & $\mathbf{7 9}$ \\
\hline c. errors of contended pairing & $\mathbf{6 5}$ \\
\hline
\end{tabular}

\subsection{Errors Of Cognate Pairing}

Cognate parings are word pairs that have the same original form and their meanings are close together (Setyawati, 2017: 94). In this cognate pairing, errors often occur because mistake in determining the form which is appropriate for expressing our ideas or not. Examples of errors of cognate pairingare as follow:

(1) Dalam lembaga bisnis pun tak terlepas dari risiko...

The word tidak and tak have the same original form and the meaning is close together, both are also standard words in Indonesian. Based on the Ministry of National Education (2008: 1460) the word tidak mean $a d v$. particle to declare denial, rejection, denial and so on. Meanwhile, the word tak based on the Ministry of National Education (2008: 1379) means adv. no, indifferent (indifferent) do not care; do not want to know, indifference, not paying attention. Correction ofthe above sentence is as follow:

- Dalam lembaga bisnis pun tidak terlepas dari risiko... 


\subsection{Errors Of Ambiguous Pairing}

The error of this ambiguous pairing is usually caused by the writer's ignorance of the correct form of the word, and is confused by the form that the writerconsiders to be correct and thus makes an error of meaning. Examples of ambiguous pairing errors are as follows:

(2) Dalam pencermatan dan pengamatan kami berbagai bahasa di sejumlah media masa nasional selama ini. Ternyata memang kami mendapatkan konjungsi atau kata penghubung itu merupakan satu-satunya problema kebahasaan yang paling banyak di buat oleh insan media diredaksi-redaksi media masa. Selain banyak ditemukan bentuk kesalahan kebahasan yang demikian itu, bentuk kebahasan ini juga sulit dipahami dan dibenahi di dalam redaksi media masa.

The use of the word masa in the sentence above shows the media used for the benefit of many people (organizations) who usually have a specific purpose or handle. In accordance with the understanding in KBBI (Indonesia Dictionary), the right word should be massa, not masa. While masa usually shows the time, for example: masa ordebaru, di masa itu, and so forth. The mistakes because of this ambiguous pairing occur because people who do not know for sure the correct form of the word and confused by the form that is considered correct. So the correction of the sentence above is as follow:

- Dalam pencermatan dan pengamatan kami berbagai bahasa di sejumlah media massa nasional selama ini. Ternyata memang kami mendapatkan konjungsi atau kata penghubung itu merupakan satu-satunya problema kebahasaan yang paling banyak di buat oleh insan media diredaksi-redaksi media massa. Selain banyak ditemukan bentuk kesalahan kebahasaan yang demikian itu, bentuk kebahasaan ini juga sulit dipahami dan dibenahi di dalam redaksi media massa.

\subsection{Errors of Contended Pairing}

Errors in contended pairing are usually due to a lack of understanding from the writer in choosing words to express meaning, because even in pairs the meanings of words are parallel. Examples of contended pairingerrors are as follow:

(3) Hubungan sekolah dan masyarakat (Husemas) adalah suatu proses komunikasi antara sekolah dengan masyarakat untuk meningkatkan pengertian masyarakat tentang kebutuhan serta kegiatan pendidikan serta mendorong minat dan kerjasama untuk masyarakat dalam peningkatan dan pengembangan sekolah.

The word pengertian and pemahaman means parallel that it knows right. But for the sentence above it is better to use the word pemahaman, because the sentence above implies it is expected not only to understand but to comprehend it as a whole. So the correction of the sentence above is as follow:

(4) Hubungan sekolah dan masyarakat (Husemas) adalah suatu proses komunikasi antara sekolah dengan masyarakat untuk meningkatkan pemahaman masyarakat tentang kebutuhan serta kegiatan pendidikan serta mendorong minat dan kerjasama untuk masyarakat dalam peningkatan dan pengembangan sekolah.

The results of the misuse of word choices or diction, in this study are as follow: 
Table 2. Word Choice or Dictionary Error

\begin{tabular}{|c|c|}
\hline Type of Semantic Level Error & Amount \\
\hline \multicolumn{2}{|l|}{ 2. Word choice or diction errors } \\
\hline $\begin{array}{l}\text { a. errors because do not meet the truth } \\
\text { requirements }\end{array}$ & 87 \\
\hline $\begin{array}{l}\text { b. errors because do not meet the accuracy } \\
\text { requirements }\end{array}$ & 89 \\
\hline $\begin{array}{l}\text { c. errors because do not meet the standard } \\
\text { requirements }\end{array}$ & 90 \\
\hline
\end{tabular}

Inappropriate word choices will cause changes in the sentence meaning and even ruinthe sentence structure, if it is not adjusted to the actual meaning or purpose of the sentence (Setyowati, 2017: 94). The best word choices according to Alwi (1992: 11) should meet the following requirements: (1) accuracy, (2) certainty, and (3) prevalence (Alwi et al, 1992: 11). If these requirements are not met, it will cause an error.

\subsection{Errors Because Do Not Meet The Truth Requirements}

The correct word is a word that is spoken or written according to the correct form (both from the basic form and the invented form). Examples of errors because do not meet the truth requirements in this study are as follow:

(5) Ketiga unsure tersebut saling mempengaruhi satu dengan yang lain.

(6) Sumber gangguan jasmani (somatic) maupun psikologis adalah stress. Apabila kita mampu mengatasi keadaan stress, perilaku kita cenderung berorientasi pada tugas (task oriented), yang intinya untuk menghadapi tuntutan keadaan. Namun, apabila stress mengancam perasaan...

The word "unsure" above If it is written so, it has the meaning of "not absolute, uncertain, not sure, do not believe", of course it is very different from the meaning entry, if it is examined deeper of the intended "unsure" above is part or contain, so the writing should be "unsur" without phoneme / e /.

The word stress is indeed similar to the word stress, but both have different meanings. Stress means stressing (English) while stres is a mental or emotional disorder or disorder caused by external factors; tension. In the sentence above what is meant is stres not stress. Corrections to the sentence above are as follow:

- $\quad$ Ketiga unsur tersebut saling mempengaruhi satu dengan yang lain.

- Sumber gangguan jasmnai (somatic) maupun psikologis adalah stres. Apabila kita mampu mengatasi keadaan stres, perilaku kita cenderung berorientasi pada tugas (task oriented), yang intinya untuk menghadapi tuntutan keadaan. Namun, apabila stres mengancam perasaan...

\subsection{Error Because Do Not Meet The Accuracy Requirements}

The correct word is a word that has meaning that can express or in accordance with the ideas of language users. Examples of errors due to not meeting the accuracy requirements in this study are as follow:

(7) Kalimat majemuk merupakan salah satu materi yang dibahas dalam Bahasa Indonesia. 
(8) Pemberian bantuan ini dapat dilakukan dengan berbagai cara, salah satu bahan yang bisa dipakai, misalnya belajar efektif, tata tertib dan sebagainya.

The word choicedibahas is not quite accurate when it is used in the above. Dibahas refers more to something that is investigated or examined. While the word dibahas in the sentence above is meant something that is taught. So, the word is dibahas more accurately if it is replaced by the word dipelajari.

In the italicized words, sentence number (7) occurs an inaccurate word choices, due to the misuse of the word causes the sentence to be difficult to understand, but if the words in italics above are replaced with words cara the sentence becomes clear and the subject becomes clear. Corrections to the sentence above are as follow:

- Kalimat majemuk merupakan salah satu materi yang dipelajari dalam Bahasa Indonesia.

- Pemberian bantuan ini dapat dilakukan dengan berbagai cara, salah satu cara yang bisa dipakai, misalnya belajar efektif, tata tertib dan sebagainya.

\subsection{Error Because Do Not Meet The Standard Requirements}

The common word is a word that is commonly used to express certain ideas. Examples of errors due to not meeting the standart requirements in this study are as follow:

(9) Sebagai hewan yang berdarah dingin, amfibi tidak aktif dalam kondisi dingin.

The word tidak aktif selected in the sentence above makes the sentence is incomprehensible. It would be better if the word tidak aktifreplaced by the word hibernasi. The word hibernasi is more commonly used in scientific terms.

(10) Adanya keberagaman ini bergantung kepada besar dan kecilnya tiap sekolah, letak sekolah dan julukan sekolah.

The word julukan refers to the person (the name given to someone, as a certain identity) is not appropriate if it is used in the sentence above, it is more common to replace the word by the word prestasi. Corrections to sentence numbers (8) and (9) as follows:

- Sebagai hewan yang berdarah dingin, amfibi tidak aktif dalam kondisi dingin

- Adanya keberagaman ini bergantung kepada besar dan kecilnya tiap sekolah, letak sekolah dan prestasi sekolah

In the word choice or diction error there are also errors due to factors influenced by the language that he mastered first as set forth by Setyawati (2017: 15). This is very possible because Indonesia is indeed composed by various islands and tribes with different languages in each tribe. Pay attention to the dataexample below:

(11) Padahal hamper semua semua permainan tradisional itu mampu memberikan lebih banyak dampak positif daripada dengan hanya bermain dengan gadget.

(12) Adanya perubahan lingkungan global semakin menyatukan hamper seluruh negara di dunia dalam komunitas tunggal, yang dijembatani perkembangan teknologi komunikasi dan informasi yang semakin murah, menuntut adanya transparasi di segala bidang..

The word hamperinfluenced by Javanese dialect, especially Central Java, preciselyfrom Blora Regency. The papers' authoris coincidence also coming from the Cepu and Pati regions. Blora's dialect is actually not too different from other Javanese dialects, there are only a few terms that are really particularly typical fromBlora, for example "nDakiya lèh?" (Isn't that right?); "Piye lèh iki ?? (How is this?). Another difference between Blora's dialect and Javanese dialect is generally the suffix "uh" becomes "oh". For example: butuh to be butoh; embuh become semboh; ngunduh becomesngundoh; suruh become suroh; utuh becomes utoh. 
Whereas the suffix "ih" becomes "èh", for example: batih becomes batèh; kluwih becomes kluwèh; Mulih becomes mulèh; sugih becomes sugèh; sapih becomes sapèh; putih becomes putèh. Sentence corrections are:

- Padahal hampir semua semua permainan tradisional itu mampu memberikan lebih banyak dampak positif daripada dengan hanya bermain dengan gadget.

- Adanya perubahan lingkungan global semakin menyatukan hampir seluruh negara di dunia dalam komunitas tunggal, yang dijembatani perkembangan teknologi komunikasi dan informasi yang semakin murah, menuntut adanya transparasi di segala bidang.

Pay attention to the other example:

(13) Kemungkinan kait-mengaitnya sopan santun dalam keluarga akan kelihatan dalam perilaku masyarakat, ...

The word formation in italics in sentences above is non-standard word forms. The error occurred because of inaccuracy in choosing the right prefix. The word is influenced by the origin of the author who came from the island of Sumatra, precisely Palembang which has B1, namely Malay, this language usually uses dialect "ke”, for example 'iyake', 'apake'.

Palembang Malay language has a very strong Javanese influence because the Sultan of Palembang in the past is estimated to have a Javanese ancestor. The main dialects are ' $O$ ' and ' $e$ ' dialects. The main example is, Palembang people often refer to themselves as wongkito (our people who are similar to urangawak in West Sumatra). It is often referred as BasoPlembang. Correction to sentence (12) should be:

(14) Kemungkinan kait-mengaitnya sopan santun dalam keluarga akan terlihat dalam perilaku masyarakat, ...

\section{Conclusion}

Semantic Errors in Students'Scientific Work from Various Indonesian Islands in the City of Madiun are divided into: (1) Usage error of similar words, consisting of (a) 88 errors of cognate pairing, (b) 79 errors of ambiguous pairing and (c) 65 errors of contended pairing. (2) Word choice (diction) errors, which consist of (a) 87 errors because do not meet the truth requirements, (b) 89 errors because do not meet the accuracy requirements, and (c) 90 errors because do not meet the standard requirements. In addition, errors in the word choices or diction occur due to factors influenced by the language that was mastered first.

Considering that there are still a lot of language errors at semantic level onstudents' scientific work in the city of Madiun, it is better for all parties, especially at the institution where the research is conducted, to implement an effective learning to overcome these problems. For example, MKU-BI (Indonesian General Course)courses are more innovative and always review students' scientific work. In addition, it can also be done by making a competition, so that the enthusiasm of students in writing scientific works is encouraged.

\section{References}

Alwi, H. (2014). Tata Bahasa Baku Bahasa Indonesia. Jakarta: Balai Pustaka

Alwi, H. dkk. (1992). Bentuk dan Pilihan Kata. Cet. Ke-1. Jakarta: Pusat Pembinaan dan Pengembangan Bahasa, Departemen Pendidikan dan Kebudayaan. 
Chaer, A. (2008). Morfologi Bahasa Indonesia (Pendekatan Proses). Jakarta: PT. Rineka Cipta.

Corder, S. P. (1981). Error Analysis and Interlanguage. Oxford: University Press.

Dalman. (2015). Menulis karya ilmiah. Depok: Rajagrafindo Persada.

Dulay, H., Burt, M., \& Krashen, S. (1982). Language Two. Oxford: Oxford University Press.

Dwiloka, B. \& Riana. (2005). Teknik Menulis Karya ilmiah. Jakarta: PT. Asdi Mahasatya

Fachrudin, A. E. (1998). Dasar-Dasar Keterampilan Menulis. Jakarta: Depdikbud.

Kurniawati, W. (2014). Reduplikasi Nomina Dalam Bahasa Indonesia: Kajian Sintaksis dan Semantik. Aksara, 26(2), 133-143.

Lyons,, John. (1977). Semantics. Volume I. Melbourne: Cambridge University Press.

Mahsun, M. S. (2005). Metode Penelitian Bahasa: Tahapan Strategi, Metode, dan Tekniknya. Jakarta: Rajawali Pers.

Masfufah, N. (2018). Sistem Fonologi Bahasa Benuq di Kabupaten Kutai Barat- Kalimantan Timur. Aksara, 30(2), 251-265.

Mulyono, S. (1964). Semantik: Ilmu Makna. Jakarta: Djambatan.

Nazir, M. (2005). Metode Penelitian. Ciawi-Bogor Selatan: Ghalia Indonesia.

Palmer, F. R. (1981). Semantics. Sydney: Cambridge University Press.

Parwati, S. A. P. E. (2015). Realisasi Fonetis Konsonan Getar Alveolar Bahasa Indonesia Pada Laki-Laki dan Perempuan Dewasa. Aksara, 27(1), 37-47.

Pranowo. (1996). Analisis Pengajaran Bahasa. Yogyakarta: Gajah Mada University Press.

Setyowati, N. (2017). Analisis Kesalahan Berbahasa Indonesia: Teori dan Praktik. Surakarta: Yuma Pustaka.

Strauss, A. \&. (2009). Dasar-Dasar Penelitian Kualitatif. Tata Langkah dan Teknik-Teknik Teoritas Data. Yogyakarta: Pustaka Pelajar Offset.

Sudaryanto. (1993). Metode dan Aneka Teknik Analisis Bahasa (Pengantar Penelitian Wahana Kebudayaan Secara Linguistik). Yogyakarta: Duta Wacana Press.

Sutarsih. (2017). Penanda Fonologi Bahasa Jawa Dalam Tuturan Masyarakat di Gang Baru Semarang. Aksara, 29(1), 90-102

Suwandi, S. (2011). Semantika Pengantar Kajian Makna. Yogyakarta: Media Perkasa.

Tarigan, H. G. (1998). Pengajaran Pemerolehan Bahasa. Jakarta: P2LPTK Departemen Pendidikan dan Kebudayaan.

Zubaidah, N. (2018). Kejar Ketertinggalan, RI Target Peringkat Pertama Publikasi Ilmiah seASEAN. Diperoleh 19 Maret 2019 dari https://risbang.ristekdikti.go.id/publikasi/ berita$\underline{\text { media/kejar-ketertinggalan-ri-target-peringkat-pertama-publikasi-ilmiah-seasean }}$ 